\title{
Specialestuderendes
}

\section{læringsudfordringer i vejledningen - nudging som handlemulighed}

Hanne Nexø Jensen, lektor, Institut for Statskundskab, Københavns Universitet.

Christina Juul Jensen, specialkonsulent, Det Samfundsvidenskabelige Fakultet, Københavns Universitet.

\section{Reviewet artikel}

Specialeskrivere møder læringsudfordringer i skriveprocessen. Hvilke læringsudfordringer, det er, og hvordan studerende og vejledere håndterer dem, er artiklens fokus. Empirien er videooptagede vejledningsmøder, hvor der er minimum to optagelser for hver vejleder og studerendes forløb. Det teoretiske afsæt er generiske læringsudfordringer i vejledningsprocesser, hvor læring opstår, når de studerende passerer en læringsudfordring. Vejledere kan bruge forståelsen af læringsudfordringer til at "nudge"- plante en idé - som en måde at få studerende til at passere læringsudfordringerne.

Specialevejledning ${ }^{1}$ er en central aktivitet på kandidatstudier. Der mangler fortsat viden om, om de studerende får vejledning, der er tilpasset deres behov og implicerer, at de lærer undervejs (Dysthe, Samara, \& Westrheim, 2006; Elmgren \& Henriksson, 2010:220; Handal \& Lauvås 2006:63; Wisker, 2012). Den viden, vi har om vejledning. er primært baseret på selvrapportering i form af interviewdata, spørgeskemabesvarelser eller dagbøger (Wichmann-Hansen, Mørcke, \& Eika, 2007:14). Det er sparsomt, hvad der er af undersøgelser af, hvad der sker i vejledningsrummet. Et dansk litteraturstudie fra 2007 fandt tre studier, hvor vejledermøder var optaget (Wichmann-Hansen et al., 2007). Flere studier er kommet til, men kun få har fokus på læringsaspektet. I et norsk projekt blev vejledning af studerende i grupper fremhævet som et vigtigt bidrag til at øge de studerendes læring og forbedre det færdige speciale (Dysthe et al., 2006; Samara, 2006). Et internationalt projekts fokus var at identificere den lærende konversation og behovet for, at vejledning bliver tilpasset den enkelte studerende, blev betonet (Wisker, Robinson, Trafford, Warnes, \& Creighton, 2003). Et dansk studie baseret på lydoptagelser identificerede forventningsafstemning, vejlederroller samt feedbackformer som vigtige elementer i forhold til studerendes læring (Jensen, 2010).

\footnotetext{
${ }^{1}$ Vejledning defineres som en aktivitet, der bør bidrage til, at studerende agerer selvstændigt og lærer aktivt (Biggs, 2003).
} 
Vi ønsker at bidrage til feltet gennem en undersøgelse af, hvilke læringsudfordringer specialeskrivere møder, og hvordan vejlederen kan medvirke til, at udfordringerne bliver til læring. Empirien er videomateriale fra udvalgte vejledningssessioner, som Juul Jensen filmede på SAMF, KU i 2011.

Teoretisk analyserer vi specialestuderendes læringsudfordringer i vejledningssituationer med afsæt i begrebslige 'tærskler' (threshold concepts) udviklet af Meyer \& Land (2003), som vi indledningsvis definerer og kobler til vejledning via Kiley \& Wisker (2009). Vejlederens håndtering af læringsudfordringer ser vi på ud fra begrebet 'nudging' (Wisker, 2012). Vi identificerer specialeskrivernes læringsudfordringer og giver eksempler på, hvordan vejlederen gennem nudging bidrager til læring.

\section{Teoretisk optik}

Internationalt har begrebet læringsudfordringer afsæt i Meyer og Lands thresholds concepts, der er disciplinspecifikke tærskelbegreber. ${ }^{2}$ Det er begreber, der er uomgængelige i forhold til at lære om og forstå et universitært fagfelt (Land et al., 2005; Land, Meyer \& Smith, 2008; Meyer \& Land, 2006). Det er en proces for studerende at passere en tærskel, hvorefter den studerende vil opfatte og arbejde med et emne på en kvalitativ ny og anderledes måde (Barradell, 2013:266; Land et al., 2005:53). Meyer og Land fremhæver en række karakteristika, der kan være repræsenteret i en læringssituation (Land et al., 2005:53; Meyer \& Land, 2003): Når den lærende har lært noget nyt, og herefter opfatter situationen, emnet eller verden på en anderledes måde, er der sket en 'transformation'. Det er et tidspunkt, hvor det nye, den lærende har tilegnet sig, ikke bliver glemt, hvorfor det er 'irreversibelt', medmindre den lærende aktivt og meget stædigt forsøger at aflære (Cousin, 2006:4). Den nyligt tillærte viden kan fungere 'integrativt' ved at bidrage til at afdække tidligere skjult viden, der knytter an til den nye viden. Den lærende kan opleve, hvordan "brikkerne falder på plads" (Cousin, 2006:4). I udgangspunktet er den nye viden afgrænset til ét tærskelbegreb, men det giver samtidig mulighed for at overskride grænsen til andre (discipliners) forståelsesrammer, hvilket Meyer \& Land karakteriserer som tilgrænsende (bounded).

I vejledningssituationer støder de studerende også på tærskler, de skal passere og håndtere for at komme videre med skrivningen. Hvor Meyer \& Land forholder sig til disciplinspecifikke begreber transformerer Kiley \& Wisker (2009) tærskelbegrebsforståelsen til conceptual thresholds, der er generiske læringsudfordringer i skriveprocesser. Læringsudfordringerne er: forskningsdesign, teoretisk fundering, metodologi og metode, argumentation, analyse og fortolkning, vidensgenerering samt forsk-

2 Threshold concepts forstås som "concepts that bind a subject together, being fundamental to ways of thinking and practising in that discipline" (Land, Cousin, Meyer, \& Davies, 2005:54). 
ningsparadigme (Kiley \& Wisker, 2009; Wisker, 2012:127) (tabel 1). De øjeblikke, hvor den studerende får en ahaoplevelse og kan arbejde begrebsligt, kritisk og kreativt på en mere kompleks måde (Wisker, 2012:105) er, når de passerer en læringsudfordring (conceptual threshold crossing) (Kiley \& Wisker, 2009). Studerende kan også opleve andre forhold, så som vejlederproblemer eller praktiske problemer, der blokerer for læring. Dermed bliver problemerne til besværlige momenter, studerende skal overvinde for at kunne lære (Wisker \& Robinson, 2012:302).

Før en tærskel i en skriveproces er passeret, befinder en studerende sig i en kort eller længerevarende 'overgangsfase' (liminal), der er præget af, at den lærende præsenterer delvise eller overfladiske forståelser af et emne eller koncept (Kiley \& Wisker, 2009:432). Et særligt træk ved fasen er, at den lærende vil opleve ny viden som besværlig eller frustrerende (troublesome knowledge) at skulle tilegne sig, da den nye viden kan være i modstrid med den lærendes eksisterende viden (Land et al., 2005:54).

Studerende oplever læringsudfordringer i deres skriveproces. Derfor er det vigtigt for vejledere at have handlemuligheder for at kunne hjælpe den studerende med at sikre, at læringsudfordringer kan omdannes til læring undervejs. Wisker opfordrer til, at vejledere "looks not merely at the processes of supervision but at the ways in which we can enable, empower or 'nudge' students to work at a critical, conceptual and creative level,..." (Wisker, 2012:105).

Wisker fremhæver nudging som en handlemulighed. At nudge er at give et lille skub $i$ en rigtig retning og fremme en ønskelig adfærd (Hansen, 2015). Nudging forstår vi som: Det at plante en idé, modsat fx det at anvise eller instruere. Vejleder kan plante en idé hos den studerende og herigennem betone i hvilken retning, det kunne være hensigtsmæssigt for den studerende at arbejde hen imod. Vejledere kan nudge studerende til at passere en læringsudfordring via fokuserede spørgsmål, som den lærende konversation er udtryk for (Wisker, 2012:15 f. og 190 ff.). Ved brug af nudging får den studerende en oplevelse af problematikken og finder selv en løsning. Det giver den studerende dybdeforståelse. Den studerende bliver aktiv medskaber i situationen og bearbejder og tilegner sig ny viden. Tærskelbegreber kan være et redskab til at forstå, at læring skal være studenterfokuseret, og her underforstået aktiverende, ellers bliver det overfladelært (Barradell, 2013:267f.). At nudge de studerende til at passere læringsudfordringer kan være en læringsstrategi, der initierer dybdelæring. 


\section{Data og metode}

Vi har udvalgt 11 videoer ud af 38 til bearbejdelse og analyse. Centralt for udvælgelsen har været, at der mindst var to optagelser med samme studerende og dennes vejleder, da vi ønskede at se, om og hvordan de studerendes læringsudfordringer blev håndteret fra møde til møde. Der er optagelser fra fire studerendes forløb fordelt på tre vejledere og fra 2-4 møder med hvert par. Alle par kommer fra samme fag. ${ }^{3} \mathrm{Da}$ læringsudfordringer begrebsligt er generiske, er det ikke i udgangspunktet et problem, at casene er fra samme fag. Juul Jensen blev inviteret til at opstille kamera ved vejledningsmøderne, hvorefter hun forlod mødet. Den ikkedeltagende observationsmetode er valgt for at intervenere mindst muligt. Vi har ikke interviewet deltagerne om kameraets betydning, selvom det kan antages, at et kamera appellerer til, at deltagerne opfører sig eksemplarisk. De medvirkende, er valgt pragmatisk ud fra kriteriet om tilgængelighed og lyst til at deltage. Vejlederne er reflekterede og kan karakteriseres som gode vejledere, der tager afsæt i de studerendes oplæg og behov. De medvirkende studerende er kompetente og kvalificerede specialeskrivere.

I analysen af materialet har vi observeret de læringsudfordringer, der er knyttet til vejledningsprocesser. Vi har set videoerne sammen og undervejs debatteret eventuelle forskellige opfattelser af, hvilke læringsudfordringer de studerende møder. Vores observationer af videoerne har dannet grundlag for systematiseringen af læringsudfordringerne i casene (tabel 1).

En svaghed ved vores datamateriale er, at læring ikke nødvendigvis bliver udtrykt verbalt på vejledermøder. Dvs. der kan være læring, der primært bliver omsat skriftligt. Vi antager, at de studerende lærer undervejs, når de ikke problematiserer udfordringen efterfølgende.

\section{Hvilke læringsudfordringer har specialeskrivere og hvordan passerer de dem?}

Alle læringsudfordringerne genfindes i vores cases. Dog er alle udfordringer ikke til stede på alle møder, og ingen af de studerende når at være konfronteret med alle typer på de møder, vi har video fra. Vi analyserer fire udfordringer, der optager tid i vejledningen på tværs af casene. Det er teori, metode, argumentation samt analyse og fortolkning. Dertil kommer andre besværlige momenter. Vi ser på, hvordan læringsudfordringerne italesættes og eventuelt passeres. Dvs. om og hvordan vejleder nudger, og om den studerende formulerer løsninger på læringsudfordringerne (Wisker, 2012:15).

\footnotetext{
${ }^{3}$ Faget er ikke nævnt, da deltagerne er lovet anonymitet.
} 


\begin{tabular}{|c|c|c|c|c|}
\hline Læringsudfordringer & Case 1 ( 3 møder) & Case 2 (4 møder) & Case 3 ( 2 møder) & $\begin{array}{lrr}\begin{array}{l}\text { Case } \\
\text { møder })\end{array} & (2 \\
\end{array}$ \\
\hline Forskningsdesign & $\begin{array}{l}\text { Vælge ift. problem- } \\
\text { formulering (3) }\end{array}$ & & & $\begin{array}{l}\text { Problemfor- } \\
\text { mulering (1) }\end{array}$ \\
\hline Teoretisk fundering & Hvilken teori? (2) & Ej overskue (1) & & $\begin{array}{l}\text { Nok/rigtig } \\
\text { teori? }(1,2)\end{array}$ \\
\hline $\begin{array}{l}\text { Metode(r) \& } \\
\text { Metodologi }\end{array}$ & & Nok data? (2) & $\begin{array}{l}\text { Viden om statistik } \\
\text { (1) }\end{array}$ & $\begin{array}{l}\text { Interview med } \\
\text { børn? (2) }\end{array}$ \\
\hline Argumentation & $\begin{array}{l}\text { Polemiserer fremfor } \\
\text { argumenterer }(1,3)\end{array}$ & $\begin{array}{l}\text { Bagvendt argu- } \\
\text { mentation (3) }\end{array}$ & $\begin{array}{l}\text { Lyde akademisk } \\
\text { (2) }\end{array}$ & \\
\hline Analyse \& fortolkning & Belæg for fund (3) & $\begin{array}{l}\text { Kobling teori og } \\
\text { empiri (2) }\end{array}$ & $\begin{array}{l}\text { Forskel på analyse } \\
\text { \& diskussion? (1) } \\
\text { Nok analyse? (2) }\end{array}$ & \\
\hline $\begin{array}{l}\text { Vidensgenerering og } \\
\text { forskningsparadigme }\end{array}$ & Nok nyt? (2) & & Ros for kritik (1) & $\begin{array}{l}\text { Eksplicit om } \\
\text { paradigme? } \\
(2)\end{array}$ \\
\hline $\begin{array}{l}\text { Andre besværlige } \\
\text { momenter }\end{array}$ & $\begin{array}{l}\text { Hvor skal hvad stå? (2, } \\
\text { 3) } \\
\text { Næste skridt? (1) } \\
\text { Formalia (3) }\end{array}$ & $\begin{array}{l}\text { Ej disposition (3) } \\
\text { Struktur (1-3) } \\
\text { Formalia (4) }\end{array}$ & $\begin{array}{l}\text { Opgavens bygge- } \\
\text { sten }(1,2) \\
\text { Næste skridt? (1) } \\
\text { Eksamen (2) }\end{array}$ & $\begin{array}{l}\text { Næste skridt? } \\
(1) \text { Formalia } \\
(2)\end{array}$ \\
\hline
\end{tabular}

Tabel 1. Læringsudfordringer i casene (tallene i parentes angiver mødegang og de grå felter er de læringsudfordringer vi analyserer i artiklen)

Udfordringer i forhold til teori kommer til udtryk på tre måder. En studerende kan ikke overskue teorien, den er besværlig $(\mathrm{C} 2,1)$. En anden tager fat i hvilken teori, der kan bidrage til at belyse specialets emne $(\mathrm{C} 1,2)$, mens en tredje vil bekræftes i valg af teori. Hun ved hvilke teorier, hun vil arbejde med, men skal have vejleders opbakning til at fastholde valget (C4). Ingen studerende passerer læringsudfordringer på møderne, men de efterfølgende møder indikerer, at de studerende træffer et valg om brug af teori. Kun én studerende tager teori op igen for at sikre sig, at hun har nok teori med $(C 4,2)$.

Metode er de konkrete måder, der anvendes, når data skal indsamles, bearbejdes og analyseres. En studerende siger, at hun har svært ved metode. Det viser sig, at hun mangler konkret viden om et statistisk begreb. Hun får den manglende viden på mødet og passerer tydeligvis en læringsudfordring i vejledningssituationen, da hun med det samme applicerer det statistiske begreb på specialet $(C 3,1)$. En anden studerende, der var i tvivl om datamængden, antager vi, har passeret læringsudfordringen, da hun ikke berører det efterfølgende (C2). De øvrige studerende går fra vejledning med input til at håndtere deres metodiske udfordringer. 
Argumentet i specialet bliver problematiseret på fire måder. En vejleder efterlyser en klarere sammenhæng i argumentationen. Den studerende får sat ord på og beskriver, hvordan hun kan strukturere opgaven på en anden måde end hidtil, så opgavens argument vil fremstå mere sammenhængende $(C 2,3)$. Selvom det er besværligt for hende at håndtere vejleders feedback (troublesome knowledge), synes hun at passere læringsudfordringen, da hun siger, hvad hun skal arbejde videre med. På det sidste møde siger vejleder, at det skrevne er "godt overordnet set $i$ forhold til forrige gang" $(\mathrm{C} 2,3)$. Om det alene er udtryk for en forbedring eller passering af en læringsudfordring, kan vi ikke vurdere. En studerende, der er usikker på, hvordan en problemformulering skal konstrueres, får vejleder til at foreslå to andre formuleringer. Den studerende befinder sig på mødet i overgangsfasen (liminal), da hun efterligner vejlederen ved at gentage, hvad han har sagt (Land et al., 2005:55) (C4). En tredje studerende er usikker på, hvordan tidligere undersøgelser og hendes egen kan og skal integreres. Vejleder kommer med input til måder at håndtere det på $(C 3,2)$. I tre tilfælde efterspørger vejledere en mere akademisk argumentation. Specielt én studerende bliver på to vejledermøder advaret mod, at argumentationen bliver polemiserende $(\mathrm{C} 1,1 \& 3)$.

Analyse og fortolkning af datamateriale er udfordringer for tre studerende. I det ene tilfælde vil den studerende gerne vide om, der er forskel på analyse og diskussion $(\mathrm{C} 3,1)$. På det efterfølgende møde vil den samme studerende gerne vide, om der er nok analyse og diskussion. $(\mathrm{C} 3,2)$. Den anden studerende, der tenderer til at polemisere, har udfordringer med analysen og vejleder minder hende om, at hun skal have belæg for sit udsagn $(\mathrm{C} 1,3)$. Ud fra mødernes indhold og vejleders gentagelser virker det ikke, som om den studerende passerer læringsudfordringen. Sidste møde slutter dog med, at den studerende takker vejleder for rigtig god vejledning, der har sat tanker i gang. Den studerende siger: "... og så tænker jeg, hvorfor gjorde jeg ikke, som hun sagde fra starten?" $(\mathrm{C} 1,3)$. Dvs. måske oplever den studerende selv at have passeret nogle tærskler. En tredje studerendes udfordring er at skrive et analytisk afsnit til specialet. I stedet for at vejleder fortæller den studerende, hvorledes den studerende kan gøre dette, nudger vejleder den studerende hen mod denne læring. Det ses ved, at vejleder skaber et refleksionsrum for den studerende. Vejleder spørger den studerende med henvisning til to tekstbidder fra den studerendes skriftlige udkast: "hvad synes du forskellen er på disse tekstafsnit?"(C2,4). Hvortil den studerende efter tænkepause fortæller, hvordan dele af teksten er mere refererende og ikke så analyserende som andre steder i teksten. Den studerende reflekterer videre og fortæller, hvordan hun synes, at hun med fordel ville kunne skære dele af teksten, hvormed teksten ville fremstå skarpere og mere akademisk. Vejleder lytter og anerkender den studerendes indsigt. Det er plausibelt at antage, at vejleder også har fundet afsnittet for 
refererende og har set det som en fornuftig idé at arbejde videre med afsnittet i en mere analytisk retning. Den studerende passerer en læringsudfordring, da vejleders input bliver integrativt $(\mathrm{C} 2,4)$. Dvs. at hun kobler eksisterende viden med ny viden og får "brikkerne til at falde på plads".

Der er tre gennemgående eksempler på andre besværlige momenter (Wisker \& Robinson, 2012) i materialet. Det er opgavens delelementer, proces samt formalia og praktiske ting.

Opgavens delelementer, dvs. hvilke kapitler består et speciale af, adskiller sig fra forskningsdesign, der angår valg af teori, metode og data, ved at være spørgsmål om metode skal være et i et selvstændigt kapitel, om der skal være en diskussion osv. En studerende spørger til, hvad der skal med i specialet, og hvor det skal stå. Det er spørgsmål, der dukker op på det andet og også på det afsluttende møde, hvor det handler om, hvorvidt konklusionen skal udgøre et selvstændigt kapitel (C1,2 \& 3). En studerende ser opbygningen af specialet på en ny, transformativ måde efter udformning af en disposition til sidste vejledermøde. En disposition, som vejleder har efterlyst siden det andet møde. Vejleder kommenterer ikke på dispositionen, selvom den studerende hele tiden refererer til den $(C 2,4)$. En tredje studerende nærmest afviser et vejlederinput om, at diskutere muligheder for teoriudvikling efter konklusionen. Den studerende gentager flere gange: "Der må ikke stå noget nyt i konklusionen." Vejleder foreslår, at det bliver kaldt afrunding i stedet for diskussion $(C 3,2)$. Den studerende undrer sig.

Eksempler, hvor der både er udtrykt usikkerhed om det faglige og processen, opstår i forhold til tvivl om: "hvordan skal jeg gå videre og hvad skal jeg være fxrdig med, når vi mødes næste gang?" Et eksempel herpå er en studerende, der har svært ved at vælge fokusområde og komme videre i processen. Vejleder taler om, at det er vigtigt at foretage valg og foreslår: "Fokusér enten på daginstitution eller skole". Hvortil den studerende udbryder: "JAAAHHH". Det bliver en ahaoplevelse for den studerende, at det er nødvendigt at træffe et valg $(C 1,1)$. En anden studerende er usikker på metoden i forhold til at interviewe børn til specialet $(\mathrm{C} 4,2)$. I stedet for, at vejleder fortæller den studerende, hvad der kunne ovevejes i forbindelse med interviewene, vælger vejleder at nudge den studerende til viden herom. Vejleder responderer på den studerendes usikkerhed ved at sige: "Du skal bare kaste dig ud $i$ det" $(\mathrm{C} 4,2)$. Den studerende svarer: "Så jeg skal bare gøre det?!" $(\mathrm{C} 4,2)$. Den studerende har været i tvivl, men skubbes ud i det ukendte via vejleder. Hun fortsætter dialogen ved at opstille potentielle scenarier for empirigenerering. Vejleder lytter og indtager rollen som djævlens advokat. Til de kritiske spørgsmål, som vejleder stiller, begynder den studerende at svare velovervejet og reflekteret. Den studerende kommer selv frem til, at hun har 
svarene som fx hvor mange informanter, der skal til, og hvorledes hun får etableret et "trygt rum" for informanterne. Vejleder afrunder ved at opsummere, at den studerende har kompetencerne til at indsamle empirien, da han kan høre, at hun har gjort sig gode overvejelser om det forestående forløb $(\mathrm{C} 4,2)$.

Formalia og praktiske spørgsmål beslaglægger op til en sjettedel af mødetiden. Det gælder spørgsmål om specialekontrakten, fx hvad skal der stå, og hvor meget skal det fylde? Andre spørgsmål er, om hvor man kan låne en diktafon $(C 4,1)$, og hvordan aflevering af specialet foregår, som vejleder lukker ned ved at sige; "det ved jeg ikke noget om, læs om det på nettet" $(\mathrm{C} 1,3)$. Endelig bruges der tid på at aftale nye møder. Et gennemgående træk ved de tre momenter, som vi har observeret, er, at de kan ses som udtryk for studerendes usikkerhed og muligvis behov for at blive bekræftet af vejleder.

Alle læringsudfordringer genfindes i materialet selvom kun ét fag er repræsenteret. Det er en understregning af, at begreberne er generiske. På alle møder er der eksempler på, at de studerende oplever en af læringsudfordringerne som besværlig, og flere giver udtryk for, at de befinder sig i en overgangsfase efter feedback fra vejleder. Det ses når den studerende ukritisk gentager, hvad vejleder har sagt. Der er en tendens til, at givne læringsudfordringer er knyttet til forskellige faser i skriveprocessen, fx forskningsdesign i starten og analyse halvvejs, men vores datamateriale er for småt til at generalisere ud fra. Der er fx også studerende, der på sidste møde har udfordringer med at træffe valg ud fra problemformuleringen.

\section{Konklusion}

Alle specialeskrivere i vores materiale møder læringsudfordringer i specialeprocessen. Vi har fokuseret på fire af de generiske udfordringer, der optager tid i vejledningen, nemlig teori, metode, argumentation samt analyse og fortolkning. Endvidere har vi identificeret andre besværlige momenter i form af opgavens komponenter, arbejdsprocessen og formalia.

I flere tilfælde giver studerende i ord udtryk for, at de passerer en læringsudfordring. Vejlederne agerer fødselshjælpere på et utal af måder: Der er vejlederen, der giver en lektion i definition og brug af et statistisk begreb P $(\mathrm{C} 3,1)$. Der er vejledere, der instruerer og fx siger: "du skal træffe et valg!" $(\mathrm{C} 1,1)$. Eller: "du skal have belæg for dine argumenter, så teksten ikke fremstår polemiserende!" (C1,3). Megen vejledningstid er optaget af, at vejleder forholder sig til spørgsmål fra de studerende; fx "hvordan kan jeg kombinere min undersøgelse med andres?" (C3,2). Eller: "har jeg nok analyse?" $(\mathrm{C} 3,2)$ Vejledere stiller også spørgsmål: "Hvad mener du, når du skriver, at ...? "eller fx, når vejleder beder den studerende om at uddybe en argumentation. 
Nudging, hvor vejlederen bevidst planter en idé ved at stille et spørgsmål, og hvor den studerende gennem refleksion selv når frem til en løsning på en læringsudfordring, er der flere eksempler på. Nudging er ikke den eneste måde, hvorpå vejledere kan håndtere studerendes læringsudfordringer, men er en tilgang, der åbner for at kombinere en spørgende, dialogorienteret tilgang til vejledning (Wichmann-Hansen \& Jensen, 2013, s. 340 ff.; Wisker, 2012:187 ff.), hvor det centrale er en aktivt reflekterende og lærende specialestuderende.

Hanne Nexø Jensen er lektor ved Institut for Statskundskab. Hun er uddannet cand.adm.pol., ph.d. Var i pædagogikum efter kandidateksamen. Har været studieleder $i 5$ år og er generel specialevejleder. Hun er mangeårig specialevejleder og har projekter om speciale- og BA-projektvejledning. Forsker derudover i forandringer $i$ og af offentlige organisationer i et kønsperspektiv.

Christina Juul Jensen er pædagogisk konsulent ved Pædagogisk Center Samfundsvidenskab, KU. Hun er uddannet cand.mag. i Pædagogik og Uuddannelsesstudier samt Psykologi. Hun har været pædagogisk konsulent $i 6$ år og arbejder primært med undervisning og supervision af underviseres undervisnings- og vejledningsudvikling og praksis. Desuden vejleder og underviser hun studerende i akademisk studieteknik og opgaveproces.

\section{Litteratur}

Barradell, S. (2013). The identification of threshold concepts: a review of theoretical complexities and methodological challenges. Higher Education, 65(2), s. 265-276.

Brown, G. \& Atkins, M. (1988). Effective Teaching in Higher Education. London: Routledge.

Cousin, G. (2006). An introduction to threshold concepts. Planet, 17, s. 4-5.

Dysthe, O., Samara, A. \& Westrheim, K. (2006). Multivoiced supervision of Master's students: a case study of alternative supervision practices in higher education. Studies in Higher Education, 31(3), s. 299-318.

Elmgren, M. \& Henriksson, A.-S. (2010). Universitetspedagogik. Stockholm: Norstedts.

Handal, G. \& Lauvås, P. (2006). Forskningsveilederen. Oslo: Cappelen, Akademisk Forlag.

Hansen, P. G. et al. (2015). I Nudge you. Retrieved January 5, 2015, from http://inudgeyou.com/

Jensen, H. N. (2010). "Det lukkede rum" - en dør på klem til specialevejledning. Dansk Universitetspædagogisk Tidsskrift, 5(8), s. 17-22.

Kiley, M. \& Wisker, G. (2009). Threshold concepts in research education and evidence of threshold crossing. Higher Education Research \& Development, 28(4), s. 431-441.

Land, R., Cousin, G., Meyer, J. H. F. \& Davies, P. (2005). Threshold concepts and troublesome knowledge (3): implications for course design and evaluation. In C. Rust (Ed.), Improving Student Learning Diversity and Inclusivity (s. 53-64). Oxford: Oxford Centre for Staff and Learning Development.

Land, R., Meyer, J. H. F. \& Smith, J. (Eds.). (2008). Threshold Concepts within the Disciplines. Rotterdam: Sense Publishers.

Meyer, J. H. F. \& Land, R. (2003). Threshold Concepts and Troublesome Knowledge: Linkages to Ways of Thinking and Practising within the Disciplines (E. T.-L. E. 
i. U. Courses, Trans.). Edinburgh: School of Education, University of Edinburgh.

Meyer, J. H. F. \& Land, R. (Eds.). (2006). Overcoming Barriers to Student Understanding: Threshold concepts and troublesome knowledge. London: Routledge.

Samara, A. (2006). Group supervision in graduate education: a process of supervision skill development and text improvement. Higher Education Research $\mathcal{E}$ Development, 25(2), s. 115-129.

Wichmann-Hansen, G. \& Jensen, T. W. (2013). Processtyring og kommunikation i vejledningen. I: Rienecker, L., Jørgensen, P. S., Dolin, J. \& Ingerslev, G. H. (red..). Universitetspædagogik (s. 329-350). Frederiksberg: Samfundslitteratur.

Wichmann-Hansen, G., Mørcke, A. M. \& Eika, B. (2007). Hvad findes der af litteratur om vejledning? - Litteratursøgning med fokus på publicerede, evidensbaserede studier. Dansk Universitetspædagogisk Tidsskrift, 2(3), s. 11-19.

Wisker, G. (2012). The Good Supervisor. Supervising Postgraduate and undergraduate Research for Doctoral Theses and Dissertations (2nd ed.). Hampshire: Palgrave Macmillan.

Wisker, G. \& Robinson, G. (2012). Doctoral 'orphans': nurturing and supporting the success of postgraduates who have lost their supervisors. Higher Education Research \& Development, 32(2), s. 300-313.

Wisker, G., Robinson, G., Trafford, V., Warnes, M. \& Creighton, E. (2003). From Supervisory Dialogues to Successful PhDs: strategies supporting and enabling the learning conversations of staff and students at postgraduate level. Teaching in Higher Education, 8 (3), s. 383-397. 